\title{
Development of an Analytical Procedure to Determine Partition Coefficients of Selected Model Migrants between Low- density Polyethylene and Polyamide and Nanocomposite Polyamide
}

\author{
Pablo Otero-Pazos ${ }^{1}$, David Antonio Pereira de Abreu ${ }^{1}$, Raquel Sendon ${ }^{*}$, Ana Rodríguez Bernaldo de \\ Quirós $^{1}$, Inmaculada Angulo²; Jose Manuel Cruz ${ }^{3}$, Perfecto Paseiro ${ }^{1}$ \\ ${ }^{1}$ Department of Analytical Chemistry, Nutrition and Bromatology, Faculty of Pharmacy, University of Santiago \\ de Compostela, 15782-Santiago de Compostela, Spain \\ ${ }^{2}$ Department of Plastic and Composites. GAIKER (Research Centre), 48170 Zamudio-Bilbao, Spain \\ ${ }^{3}$ Department of Chemical Engineering, E.T.S.E.I., University of Vigo, 36200-Vigo (Pontevedra), Spain
}

Email: raquel.sendon@usc.es

\begin{abstract}
Polymeric materials have been extensively used in food packaging. The main problem associated to plastics is the migration of low molecular substances from the material to the food, which may be potentially dangerous for the consumers' health. The key parameters of the migration are the partition and diffusion coefficients. The development of polymer nanocomposites is expected to provide new materials with enhanced properties and safer food packaging. This work describes a procedure to determine the partition coefficients of selected model substances between low-density polyethylene (LDPE) and polyamide (PA) and, between LDPE and nanocomposite polyamide (naPA). The assays were conducted at different time-temperature conditions. The model migrants were extracted from the polymeric materials with ethanol and analyzed by RP-HPLC-DAD-FLD. The values of the partition coefficients obtained ranged from 0.01 to $>1000$. The results obtained suggest that the incorporation of nanocomposites could affect the solubility of certain compounds into the polymeric matrix.
\end{abstract}

Keywords: Partition coefficient, nanocomposite, packaging, migration, polyethylene, polyamide

\section{Introduction}

From the technological point of view, nanocomposites have attracted great attention from scientists because they have characteristics and properties different to micromaterials. Organic-inorganic nanocomposites have hybrid properties derived from synergistic reactions of the two components. The most promising composite systems are nanocomposites based on organic polymers and inorganic clay minerals [1-5].

Exfoliation of nanoparticles in polymers confers considerable improvements in the properties of the polymer compared with conventionally used additives (microparticles). The improved mechanical, fireproofing and barrier properties conferred by the nanocompounds are of special interest in the food packaging industry [5-8] without any significant reduction in other relevant properties, including toughness [9-11]. In addition, another advantage is the transparency of the material due to their low filler loading, because the clay content is below a critical loading level [12] and besides, natural silicates are included in the positive list of substances which are allowed to be used in plastic materials and articles intended to come into contact with foodstuffs [13].

The transfer of substances across a polymeric matrix involves three stages: dissolution of the substance in the polymeric matrix; diffusion across the polymeric matrix, and posterior release of the substance at another part of the polymeric matrix.

In the food industry, the packages could prevent or delay one or all the stages involved in this process to increase the shelf life of the food and to increase the safety of the food to consumers. Nanocompounds act as a physical barrier that delays the passage of oxygen across the polymeric matrix containing the 
nanocompounds [14, 15]. Food packaging contains additives like antioxidants, dyes, pigments, antifogging agents, stabilizers and plasticizers. These substances are used to minimize degradation during processing, to facilitate processing and to increase stability during storage [16, 17]. The contamination of foodstuffs with substances from the packaging material could occur during the packaging process itself, for example via overprinting labels [18]. Migration includes partition and diffusion phenomena. These phenomena are important in determining the concentration of contaminants in a food system at any time and temperature. The main factors that control the migration process are partition coefficient between packaging materials, packaging composition, migrant concentration, time, temperature, molecular weight, solubility, diffusivity and, structures [19-21].

In the migration process, the kinetic (diffusion) and thermodynamic equilibrium (partition) can be defined as an exchange of mass and energy between the packaging and food [21, 22].

The key parameters of the migration are the diffusion and partition coefficients.

The diffusion coefficients (D) express the rate at which a substance diffuses into the material. The migration, generally obeys Fick's Second Law.

$$
\frac{\partial C p}{\partial t}=\frac{\partial 2 C p}{\partial x 2}
$$

where $C p$ is the concentration of the migrant in the polymer at time $\mathrm{t}(\mathrm{s})$ and position $\mathrm{x}$ and $\mathrm{D}$ is the diffusion coefficient in $\mathrm{P}\left(\mathrm{cm}^{2} / \mathrm{s}\right)$. An analytical solution of this differential equation was proposed by Crank in 1975 [21, 23].

A partition coefficient is defined as the ratio of migrant equilibrium concentration in the packaging material, $\mathrm{Cp} 1$, to its equilibrium concentration, in another packaging material phase, $\mathrm{Cp} 2 . \mathrm{K}$ is defined as: $\mathrm{K}=\mathrm{Cp} 1 / \mathrm{Cp} 2$. When $\mathrm{K}=1$, the migrant concentration in each packaging material is equal, at equilibrium. $\mathrm{K}$ is higher when more migrant is absorbed into the packaging material 1 than in the packaging material 2. Molecular size and chemical structure of migrant and temperature are the main factors that affect the partition coefficient [21].

The aim of this paper was to determine the partition coefficients of different model migrants, including trans, trans-1,4-diphenyl-1,3-butadiene (DPBD), 5-Chloro-2-(2,4-dichlorophenoxy)phenol (triclosan), Benzophenone, 2,5-bis (5-tert-butyl-2- benzoxazolyl) thiophene (Uvitex 0Bß), Diphenyl phthalate (DPP), lsopropyi-9Hthioxanthen- 9-one (ITX), Butylated hydroxyl toluene (BHT) and Bisphenol A (BPA) between the LDPE and polyamide (PA) and, between LDPE and nanocomposite polyamide (naPA).

Benzophenone and ITX are widely used as photoinitiators for UV-cured inks, DPBD belongs to fluorescent whitening agents; Triclosan is a broad-spectrum antimicrobial compound; DPP is a plasticizer, Bisphenol $\mathrm{A}$ is the starting material to produce polycarbonate; BHT is a synthetic antioxidant and Uvitex $0 \mathrm{~B} \AA$ is an optical brightening agent [3,7,13, 19-22].

The model migrants selected are widely used in food contact materials, they have different physicochemical properties and different chemical behavior. The results are commented on concerning the parameters that may affect the migration.

\section{$2 \quad$ Materials and Methods}

\subsection{Materials}

The nanocomposites used are natural montmorillonite, modified with a quaternary ammonium salt to facilitate dispersal in the polymeric matrix. Cloisite 308 nanoparticles (provided by Southern Clay Product, Texas, USA; www.scprod.com) were used. The cationic exchange capacity is $90 \mathrm{meq} / 100 \mathrm{~g}$ of clay. This montmorillonite is suitable for incorporation in polar polymeric matrix as polyamide. Polyamide $6(\mathrm{PA})$ of density $1.17 \mathrm{~g} / \mathrm{cm}^{3}$ was used.

\subsection{Chemicals and Standards}

All chemicals were of analytical grade. Ethanol, acetonitrile and tetrahydrofuran were from Merck (Darmstadt, Germany). Ultrapure water was obtained from a Milli-Q water purification system (Millipore, Bedford, MA, USA). 
Standards of Benzophenone CAS 119-61-9; (MW 182.22) and DPBD (98\%) CAS 538-81-8, (MW 206.28) were from Sigma-Aldrich (Steinheim, Germany).

Triclosan (97\%) CAS 3380-34-5; (MW 289.54), 2,5-bis (5-tert-butyl-2-benzoxazolyl) thiophene (Uvitex® OB) ( $\geqslant 99 \%$ ) CAS 7128-64-5; (MW 430.56) (SML $0.6 \mathrm{mg} / \mathrm{kg}$ ) and Butylated hydroxytoluene (BHT) ( $\geqslant 99.0 \%)$ CAS no. 128-37-0) (MW 220.35) (SML $3 \mathrm{mg} / \mathrm{kg}$ ) were obtained from Fluka (Steinheim, Germany). Bisphenol A (BPA) ( $\geqslant 99 \%$ ) CAS 80-05-7; (MW 228.29) (SML $0.6 \mathrm{mg} / \mathrm{kg}$ ); Diphenyl phthalate (DPP) ( $\geqslant 99.0 \%$ ) CAS 84-62-8; (MW 318.32) and lsopropyi-9H-thioxanthen-9-one, mixture of 2- and 4-isomers (ITX) (97\%) CAS 75081-21-9; (MW 254.35) were purchased from AldrichChemie (Steinheim, Germany).

\subsection{Standard Solutions}

A primary stock solution for each one of those migrants was prepared in ethanol $\left(500 \mu \mathrm{g} \mathrm{ml}^{-1}\right)$. Three intermediate standard solutions containing benzophenone, DPBD and Uvitex; DPP, ITX and BHT and BPA and Triclosan of a concentration of $50 \mu \mathrm{g} \mathrm{ml}^{-1}$ were prepared in ethanol. Solutions were stored in amber bottles at $4^{\circ} \mathrm{C}$ in the refrigerator.

\subsection{Films}

The model migrants were added to the LDPE films during the extrusion process:

- LDPE film (thickness: $397.7 \pm 13.9 \mu \mathrm{m} ; \mathrm{C}_{\text {Benzophenone }}=417.72 \pm 67.4 \mu \mathrm{g} \mathrm{g}^{-1} ; \mathrm{C}_{\mathrm{DPBD}}=755.0 .6 \pm 31.6 \mu \mathrm{g} \mathrm{g}^{-1}$; $\left.\mathrm{C}_{\text {Uvitex }}=900.3 \pm 55.2 \mu \mathrm{g} \mathrm{g}^{-1}\right)$ with Benzophenone, DPBD and UvitexOB.

-LDPE film (Thickness: 410.6 $\pm 16.7 \mu \mathrm{m} ; \mathrm{C}_{\mathrm{DPP}}=457.3 \pm 113.2 \mu \mathrm{g} \cdot \mathrm{g}^{-1} ; \mathrm{C}_{\mathrm{ITX}}=1138.0 \pm 206.9 \mu \mathrm{g} \mathrm{g} \mathrm{g}^{-1}$; $\left.\mathrm{C}_{\mathrm{BHT}}=839.8 \pm 170.3 \mu \mathrm{g} \mathrm{g}^{-1}\right)$ with DPP, ITX and BHT.

- LDPE film (Thickness: $394.8 \pm 17.6 \mu \mathrm{m} ; \mathrm{C}_{\mathrm{BPA}}=933.7 \pm 57.5 \mu \mathrm{g} \mathrm{g}^{-1} ; \mathrm{C}_{\text {Triclosan }}=1233.1 \pm 85.1 \mu \mathrm{g} \mathrm{g}^{-1}$ ) with BPA and Triclosan.

Films were made by cast extrusion technique. Prior to the extrusion process the Polyamide 6 was dried at $80{ }^{\circ} \mathrm{C}$ for 24 hours. The composites were prepared by melt compounding using a co-rotating twin screw extruder (Micro 27 GL-36 D Leistritz). The screw diameter was $27 \mathrm{~mm}$, screw length, $36 \mathrm{X}$ $\mathrm{D}$, and screw speed range, $10-400 \mathrm{rpm}$.

The exfoliated film was developed following the methodology described by Pereira et al. [15]. The barrel was set at $220-240{ }^{\circ} \mathrm{C}$; Zone 1 and 11 at $220{ }^{\circ} \mathrm{C}$, Zone 111 at $225{ }^{\circ} \mathrm{C}$, Zone IV and $\mathrm{V}$ at $230{ }^{\circ} \mathrm{C}$, Zone VI and VII at $235^{\circ} \mathrm{C}$ and Zone VIII and IX at $240{ }^{\circ} \mathrm{C}$. The inorganic contents of the samples were calculated by measuring the weight before and after burning the organic component. The concentration of Cloisite 308 in the nanocomposites was $5 \%(w / w)$ in all cases. For reference purposes, neat polyamide without nanoparticles was also extruded.

\subsection{Experimental Procedure}

Films (LDPE, Polyamide and nanocomposite polyamide) were cut in pieces of $4 \times 4 \mathrm{~cm}^{2}$. The thickness along each side of the film was measured by triplicate, and the average value was calculated. LDPE film was put in contact with one of the faces of polyamide or nanocomposite polyamide. Samples were then wrapped with aluminium foil to protect them from the light, then were placed inside a transparent plastic bag, and incubated in the oven at 60 and $80^{\circ} \mathrm{C}$. The incubation times used were 40,55 , and 70 days for $60{ }^{\circ} \mathrm{C}$ and 25,40 and 60 days for $80{ }^{\circ} \mathrm{C}$, respectively. Then, at selected times, the set was retired of the oven and removed the additivated LDPE film and the other plastic (polyamide or nanocomposite polyamide). After this, the extraction from additivated LDPE, polyamide and nanocomposite polyamide films was carried out.

The films were put in a $60 \mathrm{ml}$ amber flask, $50 \mathrm{ml}$ of ethanol was added with a volumetric pipette and incubated for 6 hours at $70{ }^{\circ} \mathrm{C}$. After this time, the flask was retired of the oven and separated the plastic from the liquid phase. An aliquot of the liquid phase was filtered by a $0.50 \mu \mathrm{m}$ filter and analyzed by HPLC. 


\subsection{Chromatography}

The model migrants were analysed by using a chromatographic system (Hewlett-Packard, Waldbronn, Germany) consisted of an HP1100 quaternary pump, a degassing device, an autosampler, a column therrnostatting system, a diode-array detector (DAD), and fluorescence detector. HP ChemStation chromatographic software was used for data acquisition. A reversed-phase Kromasil 100 C18 column (25 x $0.36 \mathrm{~cm}$ l.D., $5 \mu \mathrm{m}$ particle size) thermostated at $30{ }^{\circ} \mathrm{C}$ was used. The flow-rate was $0.5 \mathrm{ml} \mathrm{min}^{-1}$ and the injection volume was $20 \mu \mathrm{l}$ for benzophenone, DPBD and Uvitex and 10 $\mu$ l for the other analytes.

Three gradient elution systems were used for the determination of the model migrants. The mobile phases used for the analysis of benzophenone, DPBD and Uvitex consisted of A (Milli-Q water) and B (THF 30\% methanolic solution v/v). The gradient elution conditions were as follows: 0 min $(30 \% \mathrm{~A}$ $70 \% \mathrm{~B}) ; 4 \min (30 \% \mathrm{~A} 70 \% \mathrm{~B}) ; 10 \mathrm{~min}(0 \% \mathrm{~A} \mathrm{100 \% B}) ; 17 \min (0 \% \mathrm{~A} \mathrm{100 \% B})$. Post-time: $3 \mathrm{~min}$.

For the analysis of DPP, ITX and BHT the elution system was composed by A (Milli-Q water) and B (acetonitrile). The gradient elution programme was as follows: 0 min $(40 \% \mathrm{~A} 60 \% \mathrm{~B}) ; 1$ min $(40 \% \mathrm{~A}$ $60 \% \mathrm{~B}) ; 17 \min (0 \% \mathrm{~A} 100 \% \mathrm{~B}) ; 20 \mathrm{~min}(0 \% \mathrm{~A} 100 \% \mathrm{~B})$. Post-time: $5 \mathrm{~min}$. In the case of BPA and triclosan, the mobile phase also consisted of $\mathrm{A}$ (Milli-Q water) and $\mathrm{B}$ (acetonitrile) and the gradient elution was as following: $0 \min (40 \% \mathrm{~A} 60 \% \mathrm{~B}) ; 3 \min (40 \% \mathrm{~A} 60 \% \mathrm{~B}) ; 9 \min (0 \% \mathrm{~A} 100 \% \mathrm{~B}) ; 17 \mathrm{~min}(0 \% \mathrm{~A}$ 100\%B). Post-time: 5 min. DPP, BHT and triclosan were detected at $205 \mathrm{~nm}$, benzophenone at $256 \mathrm{~nm}$, DPBD at $330 \mathrm{~nm}$, and Uvitex at $372 \mathrm{~nm}$. The FLD detector was set at $\lambda$ em $410 \mathrm{~nm}$ and $\lambda$ ex $250 \mathrm{~nm}$ for ITX and at $\lambda$ em $305 \mathrm{~nm}$ and $\lambda$ ex $225 \mathrm{~nm}$ for BPA.

\section{$3 \quad$ Results and Discussion}

The partition coefficients of low-density polyethylene/polyamide ( $\left.\mathrm{K}_{\mathrm{LDPE} / \mathrm{PA}}\right)$ and low-density polyethylene/nanocomposite polyamide $\left(\mathrm{K}_{\mathrm{LDPE} / \mathrm{naPA}}\right)$, i.e., the relative solubility of the migrant at equilibrium between the polyethylene and the polyamide or nanocomposite polyamide are shown in Tables 1 and 2, respectively. It is interesting to note that some substances have not reached the equilibrium at the end of experiment. Partition coefficient of LDPE/polyamide or nanocomposite polyamide for each model substance was calculated using the following equation:

$$
K_{L D P E} / P_{A}=\frac{C_{L D P E e q}}{C_{P A e q}} \quad K_{L D P E} /{ }_{n a P A}=\frac{C_{L D P E e q}}{C_{n a P A e q}}
$$

where: $\mathrm{K}_{\mathrm{LDPE} / \mathrm{PA}}$ is the partition coefficient between LDPE and polyamide;

$\mathrm{K}_{\mathrm{LDPE} / \mathrm{naPA}}$ is the partition coefficient between LDPE and nanocomposite polyamide;

$\mathrm{C}_{\text {PAeq }}$ is the concentration of substance in polyamide at equilibrium, in $\mu \mathrm{g} \mathrm{g}^{-1}$;

$\mathrm{C}_{\text {naPAeq }}$ is the concentration of substance in nanocomposite polyamide at equilibrium, in $\mu \mathrm{g} \mathrm{g}^{-1}$;

$\mathrm{C}_{\mathrm{LDPEeq}}$ is the concentration of substance in the LDPE at equilibrium, in $\mu \mathrm{g} \mathrm{g}^{-1}$;

Physico-chemical features of the model migrants such as polarity, solubility and hydrogen-bonding as well as the material used in the manufacture of the packaging are factors that influence the partition coefficient. Due to the large sizes of the polymer molecules, the secondary bond forces (van der Waals forces and hydrogen bonding) assume much greater roles in influencing physical properties than they do in small organic molecules [24].

Low molecular weight molecules compared with those with high molecular weight are absorbed more rapidly due to the greater diffusivity. Indeed, the partition coefficient of a series of compounds with the same functional group (i.e. esters or aldehydes) increased with increasing carbon chain length [21, 25-30]. The alcohols in aqueous solutions increase its partition coefficients to increasing its molecular weight.

This could be the result of decreased solubility of alcohols when the chain of alcohols is increased due to increased repulsive forces between water and alcohol molecules [31].

In effect, larger molecules are absorbed to a larger extent than the smaller ones and highly branched molecules are absorbed to a greater extent than linear molecule into non-polar polyolefins [29]. The differences between the polarity of migrant and polymer are key parameters in the absorption process [21]. Alcohols and short-chained esters (polar substances) have higher partition coefficients in the oil/polymer system than in the water/polymer system. Whereas, aldehydes (long carbon non-polar chains) have lower partition coefficients in the oil/polymer, than in the water/polymer [29]. In mixtures, some compounds exhibit a lower absorption rate that systems containing the individual compounds. 
This effect could be explained due to the absorbed components changing the properties of polymer and/or the compounds competing for a limited number of active sorption sites [29,30]. When more than one type of solids are present, alcohols preferentially are adsorbed to the solid with higher affinity for alcohols, until all binding sites on the solid have been occupied. Silica and soy protein increases solubility of alcohols in water by adsorbing them through hydrophobic association and/or hydrogen bonds [31]. Uvitex, ITX, DPBD, DPP, Benzophenone and BHT show a $\mathrm{K}_{\mathrm{LDPE} / \mathrm{PA}}$ and $\mathrm{K}_{\mathrm{LDPE} / \mathrm{naPA}}$ far-off and higher than 1 . Triclosan $\left(80^{\circ} \mathrm{C}\right)$ and BPA show the smallest partition coefficient of low-density polyethylene/polyamide $\left(\mathrm{K}_{\mathrm{LDPE} / \mathrm{PA}}\right)$ and low-density polyethylene/nanocomposite polyamide $\left(\mathrm{K}_{\mathrm{LDPE} / \mathrm{naPA}}\right)$. Cloisite $30 \mathrm{~B}$ and polyamide have polar groups. These areas could attract and form hydrogen bonds and van der Waals forces bonds with migrants from the polyethylene. Owing the composition of

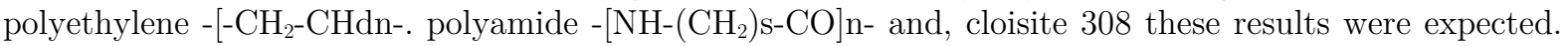
Polymer/silicate nanocomposites have better properties such as high barrier properties, improved tensile characteristics, higher heat deflection temperature, better scratch resistance, and increased flame retardancy $[14,15,32,33]$. BPA is a molecule that has two polar groups in its structure that provides a polar surface area of $40.46 \mathrm{~A}^{2}$. The polar surface area of a molecule is defined as the area of its van der Waals surface that arises from oxygen or nitrogen atoms or hydrogen atoms attached to oxygen or nitrogen atoms. As such, it is clearly related to the capacity of a compound to form hydrogen bonds [34]. The presence of polar groups, their size, their ability to form hydrogen bonds and van der Waals bonds could explain why the solubility of BPA into the polyamide was favored. On the other hand, in the case of Uvitex, the amount migrated at $80{ }^{\circ} \mathrm{C}$ (60 days) from the LDPE to the polyamide was negligible although the Uvitex has polar groups and can form secondary bonds. In this case, the great partition coefficient could be due to the large size of Uvitex.

Tables 1 and 2 show the Partition coefficients of polyethylene/polyamide $\left(\mathrm{K}_{\mathrm{LDPE} / \mathrm{PA}}\right)$ and polyethylene/nanocomposite polyamide $\left(\mathrm{K}_{\mathrm{LDPE} / \mathrm{naPA}}\right)$ at $60{ }^{\circ} \mathrm{C}$ and $80{ }^{\circ} \mathrm{C}$ for all substances studied, respectively.

$\mathrm{R}_{\mathrm{PA} / \mathrm{naPA}}$ is a relative measure of the times that a substance is soluble in PA instead of naPA at equilibrium. Relation $\left(\mathrm{R}_{\mathrm{PP} / \mathrm{naPP}}\right)$ between $\mathrm{K}_{\mathrm{LDPE} / \mathrm{PA}}$ and $\mathrm{K}_{\mathrm{LDPE} / \mathrm{naPA}}$ at $60{ }^{\circ} \mathrm{C}$ and $80{ }^{\circ} \mathrm{C}$ for all substances studied is shown in Table 3.

$\mathrm{R}_{\mathrm{PA} / \mathrm{naPA}}$ is defined as:

$$
R_{P A / n a P A}=\frac{K_{L D P E} / P A}{K_{L D P E} / n a P A}
$$

Table 1. Partition coefficients of polyethylene/polyamide (KLDPE/PA) at $60{ }^{\circ} \mathrm{C}$ and $80{ }^{\circ} \mathrm{C}$ for all substances studied.

\begin{tabular}{|c|c|c|c|}
\hline Model migrant & KLDPE/PA & Model migrant & KLDPE/PA \\
\hline Benzophenone $60{ }^{\circ} \mathrm{C}$ and 40 days & 8.30 & DPP $60{ }^{\circ} \mathrm{C}$ and 40 days & 44.20 \\
\hline Benzophenone $60{ }^{\circ} \mathrm{C}$ and 55 days & 9.25 & DPP $60^{\circ} \mathrm{C}$ and 55 days & 45.65 \\
\hline Benzophenone $60^{\circ} \mathrm{C}$ and 70 days & 8.12 & DPP $60^{\circ} \mathrm{C}$ and 70 days & 42.73 \\
\hline Benzophenone $80{ }^{\circ} \mathrm{C}$ and 25 days & 6.84 & DPP $80^{\circ} \mathrm{C}$ and 25 days & 26.68 \\
\hline Benzophenone $80{ }^{\circ} \mathrm{C}$ and 40 days & 4.26 & DPP $80^{\circ} \mathrm{C}$ and 40 days & 31.80 \\
\hline Benzophenone $80{ }^{\circ} \mathrm{C}$ and 60 days & 2.99 & DPP $80{ }^{\circ} \mathrm{C}$ and 60 days & 10.71 \\
\hline DPBD $60{ }^{\circ} \mathrm{C}$ and 40 days & 41.66 & BHT $60{ }^{\circ} \mathrm{C}$ and 40 days & 4.46 \\
\hline $\mathrm{DPBD} 60^{\circ} \mathrm{C}$ and 55 days & 51.40 & BHT $60{ }^{\circ} \mathrm{C}$ and 55 days & 6.90 \\
\hline DPBD $60{ }^{\circ} \mathrm{C}$ and 70 days & 41.62 & BHT $60{ }^{\circ} \mathrm{C}$ and 70 days & 10.24 \\
\hline DPBD $80{ }^{\circ} \mathrm{C}$ and 25 days & 33.40 & BHT $80{ }^{\circ} \mathrm{C}$ and 25 days & 5.83 \\
\hline DPBD $80{ }^{\circ} \mathrm{C}$ and 40 days & 24.00 & BHT $80{ }^{\circ} \mathrm{C}$ and 40 days & - \\
\hline DPBD $80{ }^{\circ} \mathrm{C}$ and 60 days & 18.53 & BHT $80{ }^{\circ} \mathrm{C}$ and 60 days & 2.69 \\
\hline Uvitex $60{ }^{\circ} \mathrm{C}$ and 40 days & $>1000$ & Bisphenol A $60{ }^{\circ} \mathrm{C}$ and 40 days & 0.31 \\
\hline Uvitex $60{ }^{\circ} \mathrm{C}$ and 55 days & $>1000$ & Bisphenol A $60{ }^{\circ} \mathrm{C}$ and 55 days & 0.25 \\
\hline Uvitex $60{ }^{\circ} \mathrm{C}$ and 70 days & $>1000$ & Bisphenol A $60{ }^{\circ} \mathrm{C}$ and 70 days & 0.25 \\
\hline Uvitex $80{ }^{\circ} \mathrm{C}$ and 25 days & $>1000$ & Bisphenol A $80{ }^{\circ} \mathrm{C}$ and 25 days & 0.13 \\
\hline
\end{tabular}




\begin{tabular}{|c|c|c|c|}
\hline Uvitex $80{ }^{\circ} \mathrm{C}$ and 40 days & $>1000$ & Bisphenol A $80{ }^{\circ} \mathrm{C}$ and 40 days & 0.03 \\
\hline Uvitex $80^{\circ} \mathrm{C}$ and 60 days & $>1000$ & Bisphenol A $80{ }^{\circ} \mathrm{C}$ and 60 days & 0.04 \\
\hline ITX $60{ }^{\circ} \mathrm{C}$ and 40 days & 98.71 & Triclosan $60{ }^{\circ} \mathrm{C}$ and 40 days & 2.07 \\
\hline ITX $60{ }^{\circ} \mathrm{C}$ and 55 days & 85.29 & Triclosan $60^{\circ} \mathrm{C}$ and 55 days & 1.64 \\
\hline ITX $60{ }^{\circ} \mathrm{C}$ and 70 days & 81.10 & Triclosan $60{ }^{\circ} \mathrm{C}$ and 70 days & 1.66 \\
\hline ITX $80{ }^{\circ} \mathrm{C}$ and 25 days & 56.72 & Triclosan $80^{\circ} \mathrm{C}$ and 25 days & 0.92 \\
\hline ITX $80{ }^{\circ} \mathrm{C}$ and 40 days & 38.02 & Triclosan $80{ }^{\circ} \mathrm{C}$ and 40 days & 0.66 \\
\hline ITX $80{ }^{\circ} \mathrm{C}$ and 60 days & 26.43 & Triclosan $80^{\circ} \mathrm{C}$ and 60 days & 0.65 \\
\hline
\end{tabular}

Table 2. Partition coefficients of polyethylene/nanocomposite polyamide (KLDPE/naPA) at $60{ }^{\circ} \mathrm{C}$ and $80{ }^{\circ} \mathrm{C}$ for all substances studied.

\begin{tabular}{|c|c|c|c|}
\hline Model migrant & KLDPE/naPA & Model migrant & KLDPE/naPA \\
\hline Benzophenone $60{ }^{\circ} \mathrm{C}$ and 40 days & 9.24 & $\mathrm{DPP} 60^{\circ} \mathrm{C}$ and 40 days & 53.76 \\
\hline Benzophenone $60{ }^{\circ} \mathrm{C}$ and 55 days & 9.76 & DPP $60{ }^{\circ} \mathrm{C}$ and 55 days & 74.30 \\
\hline Benzophenone $60{ }^{\circ} \mathrm{C}$ and 70 days & 8.29 & DPP $60{ }^{\circ} \mathrm{C}$ and 70 days & 78.40 \\
\hline Benzophenone $80{ }^{\circ} \mathrm{C}$ and 25 days & - & DPP $80{ }^{\circ} \mathrm{C}$ and 25 days & 47.23 \\
\hline Benzophenone $80{ }^{\circ} \mathrm{C}$ and 40 days & - & DPP $80{ }^{\circ} \mathrm{C}$ and 40 days & 50.61 \\
\hline Benzophenone $80{ }^{\circ} \mathrm{C}$ and 60 days & 10.19 & DPP $80{ }^{\circ} \mathrm{C}$ and 60 days & 31.19 \\
\hline DPBD $60{ }^{\circ} \mathrm{C}$ and 40 days & 48.66 & BHT $60{ }^{\circ} \mathrm{C}$ and 40 days & 4.88 \\
\hline DPBD $60{ }^{\circ} \mathrm{C}$ and 55 days & 55.17 & BHT $60{ }^{\circ} \mathrm{C}$ and 55 days & - \\
\hline DPBD $60{ }^{\circ} \mathrm{C}$ and 70 days & 38.14 & BHT $60{ }^{\circ} \mathrm{C}$ and 70 days & 39.70 \\
\hline DPBD $80{ }^{\circ} \mathrm{C}$ and 25 days & - & BHT $80{ }^{\circ} \mathrm{C}$ and 25 days & 26.32 \\
\hline DPBD $80{ }^{\circ} \mathrm{C}$ and 40 days & 26.20 & BHT $80{ }^{\circ} \mathrm{C}$ and 40 days & - \\
\hline DPBD $80{ }^{\circ} \mathrm{C}$ and 60 days & 36.92 & BHT $80{ }^{\circ} \mathrm{C}$ and 60 days & 9.60 \\
\hline Uvitex $60{ }^{\circ} \mathrm{C}$ and 40 days & $>1000$ & Bisphenol A $60{ }^{\circ} \mathrm{C}$ and 40 days & 0.60 \\
\hline Uvitex $60{ }^{\circ} \mathrm{C}$ and 55 days & $>1000$ & Bisphenol $\mathrm{A} 60^{\circ} \mathrm{C}$ and 55 days & 0.52 \\
\hline Uvitex $60{ }^{\circ} \mathrm{C}$ and 70 days & $>1000$ & Bisphenol $\mathrm{A} 60^{\circ} \mathrm{C}$ and 70 days & 0.56 \\
\hline Uvitex $80{ }^{\circ} \mathrm{C}$ and 25 days & $>1000$ & Bisphenol A $80{ }^{\circ} \mathrm{C}$ and 25 days & 0.05 \\
\hline Uvitex $80{ }^{\circ} \mathrm{C}$ and 40 days & $>1000$ & Bisphenol A $80{ }^{\circ} \mathrm{C}$ and 40 days & 0.03 \\
\hline Uvitex $80{ }^{\circ} \mathrm{C}$ and 60 days & $>1000$ & Bisphenol A $80{ }^{\circ} \mathrm{C}$ and 60 days & 0.01 \\
\hline ITX $60{ }^{\circ} \mathrm{C}$ and 40 days & 73.59 & Triclosan $60{ }^{\circ} \mathrm{C}$ and 40 days & 2.62 \\
\hline ITX $60{ }^{\circ} \mathrm{C}$ and 55 days & 75.94 & Triclosan $60^{\circ} \mathrm{C}$ and 55 days & 2.58 \\
\hline ITX $60{ }^{\circ} \mathrm{C}$ and 70 days & 94.12 & Triclosan $60^{\circ} \mathrm{C}$ and 70 days & 2.60 \\
\hline ITX $80{ }^{\circ} \mathrm{C}$ and 25 days & 53.01 & Triclosan $80^{\circ} \mathrm{C}$ and 25 days & 1.13 \\
\hline ITX $80{ }^{\circ} \mathrm{C}$ and 40 days & 54.76 & Triclosan $80^{\circ} \mathrm{C}$ and 40 days & 0.76 \\
\hline ITX $80{ }^{\circ} \mathrm{C}$ and 60 days & 27.33 & Triclosan $80{ }^{\circ} \mathrm{C}$ and 60 days & 0.40 \\
\hline
\end{tabular}

Table 3. Relation KLDPE/PA/ KLDPE/naPA at $60{ }^{\circ} \mathrm{C}$ and $80^{\circ} \mathrm{C}$.

\begin{tabular}{|c|c|c|c|}
\hline Model migrant & $\begin{array}{l}\mathrm{KLDPE} / \mathrm{PA} / \\
\mathrm{KLDPE} / \mathrm{naPA}\end{array}$ & Model migrant & $\begin{array}{l}\mathrm{KLDPE} / \mathrm{PA} / \\
\mathrm{KLDPE} / \mathrm{naPA}\end{array}$ \\
\hline Bisphenol A $60{ }^{\circ} \mathrm{C}$ and 40 days & 0.52 & Triclosan $60{ }^{\circ} \mathrm{C}$ and 40 days & 0.79 \\
\hline Bisphenol $\mathrm{A} 60{ }^{\circ} \mathrm{C}$ and 55 days & 0.48 & Triclosan $60^{\circ} \mathrm{C}$ and 55 days & 0.64 \\
\hline Bisphenol A $60{ }^{\circ} \mathrm{C}$ and 70 days & 0.45 & Triclosan $60 \stackrel{\circ}{ } \mathrm{C}$ and 70 days & 0.64 \\
\hline Bisphenol A $80{ }^{\circ} \mathrm{C}$ and 25 days & 2.60 & Triclosan $80^{\circ} \mathrm{C}$ and 25 days & 0.81 \\
\hline Bisphenol A $80{ }^{\circ} \mathrm{C}$ and 40 days & 1.00 & Triclosan $80{ }^{\circ} \mathrm{C}$ and 40 days & 0.87 \\
\hline Bisphenol A $80{ }^{\circ} \mathrm{C}$ and 60 days & 4.00 & Triclosan $80{ }^{\circ} \mathrm{C}$ and 60 days & 1.63 \\
\hline BHT $60{ }^{\circ} \mathrm{C}$ and 40 days & 0.91 & $\mathrm{DPP} 60^{\circ} \mathrm{C}$ and 40 days & 0.82 \\
\hline BHT $60{ }^{\circ} \mathrm{C}$ and 55 days & - & DPP $60{ }^{\circ} \mathrm{C}$ and 55 days & 0.61 \\
\hline
\end{tabular}




\begin{tabular}{|c|c|c|c|}
\hline BHT $60{ }^{\circ} \mathrm{C}$ and 70 days & 0.26 & DPP $60{ }^{\circ} \mathrm{C}$ and 70 days & 0.55 \\
\hline BHT $80^{\circ} \mathrm{C}$ and 25 days & 0.22 & DPP $80{ }^{\circ} \mathrm{C}$ and 25 days & 0.56 \\
\hline BHT $80^{\circ} \mathrm{C}$ and 40 days & - & DPP $80{ }^{\circ} \mathrm{C}$ and 40 days & 0.63 \\
\hline BHT $80{ }^{\circ} \mathrm{C}$ and 60 days & 0.28 & DPP $80{ }^{\circ} \mathrm{C}$ and 60 days & 0.34 \\
\hline Benzophenone $60{ }^{\circ} \mathrm{C}$ and 40 days & 0.90 & DPBD $60{ }^{\circ} \mathrm{C}$ and 40 days & 0.86 \\
\hline Benzophenone $60{ }^{\circ} \mathrm{C}$ and 55 days & 0.95 & DPBD $60{ }^{\circ} \mathrm{C}$ and 55 days & 0.93 \\
\hline Benzophenone $60{ }^{\circ} \mathrm{C}$ and 70 days & 0.98 & DPBD $60{ }^{\circ} \mathrm{C}$ and 70 days & 1.09 \\
\hline Benzophenone $80{ }^{\circ} \mathrm{C}$ and 25 days & - & DPBD $80{ }^{\circ} \mathrm{C}$ and 25 days & - \\
\hline Benzophenone $80{ }^{\circ} \mathrm{C}$ and 40 days & - & DPBD $80^{\circ} \mathrm{C}$ and 40 days & 0.92 \\
\hline Benzophenone $80{ }^{\circ} \mathrm{C}$ and 60 days & 0.29 & DPBD $80{ }^{\circ} \mathrm{C}$ and 60 days & 0.50 \\
\hline ITX $60{ }^{\circ} \mathrm{C}$ and 40 days & 1.34 & ITX $80{ }^{\circ} \mathrm{C}$ and 25 days & 1.07 \\
\hline ITX $60{ }^{\circ} \mathrm{C}$ and 55 days & 1.12 & ITX $80{ }^{\circ} \mathrm{C}$ and 40 days & 0.69 \\
\hline ITX $60{ }^{\circ} \mathrm{C}$ and 70 days & 0.86 & ITX $80{ }^{\circ} \mathrm{C}$ and 60 days & 0.97 \\
\hline
\end{tabular}

When $\mathrm{R}=1$, the migrant absorbed in naPA at equilibrium equals to that absorbed in $\mathrm{PA}$ at equilibrium. $\mathrm{R}$ is higher than 1 when more migrant is absorbed into the naPA than in the PA. In general, BHT and DPP presented the lowest values, while ITX, BPA and triclosan exhibited the higher values. The incorporation of cloisite to PA increased the affinity of BHT, DPP and benzophenone more than the PA.

It is interesting to remark, the similar behavior of the two type of plastics used in the experiment. In some cases of the selected model substances, the equilibrium was not reached, but nevertheless the trend in these cases is that the solubilities of these compounds are similar ( $\mathrm{K}$ close to 1 ). Bisphenol A and Triclosan show slightly higher solubility in the PA than in the naPA. They are the two unique molecules with its $-\mathrm{OH}$ groups with no steric impediments and it is possible that they have more affinity with chains of PA that included polar groups themselves. Heavy molecular weight substances, as Uvitex, DPP and ITX, have very limited solubility in both plastics.

\section{Conclusion}

Briefly, in the present study the partition coefficients of selected model migrants between the LDPE and polyamide (PA) and, between LDPE and nanocomposite polyamide (naPA) at different timetemperature conditions were determined. The results obtained suggest a similar solubility in both polymers with a high capacity of avoid diffusion of high molecular weight substances as Uvitex, DPP and ITX.

The following section shows a sample reference list with entries for journal articles [1], a book chapter [2], a book [3], proceedings without editors [4] and [5], as well as a URL [6]. Please note that proceedings published in ISP are not cited with their full titles, but with their acronyms!

\section{References}

1. S. Blomberg, S. Ostberg, E. Harth, A. W. Bosman, B.Van Horn and C. J. Hawker, "Production of crosslinked, hollow nanoparticles by surface-initiated living free-radical polymerization", Journal of Polymer Science: Part A: Polymer Chemistry, vol. 40, pp. 1309-1320, 2002.

2. T. Ahmad, K. V. Ramanujachary, S. E. Lofland and A. K Ganguli, "Nanorods of manganese oxalate: a single source precursor to different manganese oxide nanoparticles (MnO, Mn2O3, Mn3O4)", Journal of Materials Chemistry, vol. 14, pp. 3406-3410, 2004.

3. S. Deki, S. Lizuka, A. Horie, M. Mizuhata and A. Kajinami, "Nanofabrication of metal oxide thin films and nano-ceramics from aqueous solution", Journal of Materials Chemistry, vol. 14, pp. 3127-3132, 2004.

4. K. Litina, A. Miriouni, D. Gournis, M. A. Karakassides, N. Georgiou, E. Klontzas, E. Ntoukas and A. Avgeropoulos, "Nanocomposites of polystyrene-b-polyisoprene copolymer with layered silicates and carbon nanotubes", European Polymer Journal, vol. 42, pp. 2098-2107, 2006. 
5. S. Y. Moon, J. K. Kim, C. Nah and Y. S. Lee, "Polyurethane/montmorillonite nanocomposites prepared from crystalline polyols, using 1,4-butanediol and organoclay hybrid as chain extenders", European Polymer Journal, vol. 40, pp. 1615-1621, 2004.

6. L. M. Döppers, C. Breen and C. Sammon, "Diffusion of water and acetone into poly(vinyl alcohol)-clay nanocomposites using ATR-FTIR", Vibrational Spectroscopy, vol. 35, pp. 27-32, 2004.

7. C. Ding, B. Guo, H. He, D. Jia and H. Hong, "Preparation and structure of highly confined intercalated polystyrene/montmorillonite nanocomposite via a two-step method", European Polymer Journal, vol. 41, pp. 1781-1786, 2005.

8. H. Li, Y. Yu and Y. Yang, "Synthesis of exfoliated polystyrene/montmorillonite nanocomposite by emulsion polymerization using a zwitterion as the clay modifier", European Polymer Journal, vol. 41, pp. 2016-2022, 2005.

9. M. Alexandre and P. Dubois, "Polymer-layered silicate nanocomposites: preparation, properties and uses of a new class of materials", Materials Science \& Engineering R-Reports, vol. 28, pp. 1-63, 2000.

10.R. Kotsilkova, V. Petkova and Y. Pelovski, "Thermal analysis of polymer-silicate nanocomposites", Journal of Thermal Analysis and Calorimetry, vol. 64, pp. 591-598, 2001.

11.M. Zanetti, G. Camino, R. Thomann and R. Mülhaupt," Synthesis and thermal behaviour of layered silicateEVA nanocomposites", Polymer, vol. 42, no. 10, pp. 4501-4507, 2001.

12.C. Wan, X. Qiao, Y. Zhang and Y. Zhang, " Effect of different clay treatment on morphology and mechanical properties of PVC-clay nanocomposites", Polymer Testing, vol. 22, pp. 453-461, 2003.

13. Commission Regulation (EU) No 10/2011 of 14 January 2011 on plastic materials and articles intended to come into contact with food. Official Journal of the European Union, L12, pp.1-132, 2011.

14.D. Pereira de Abreu, P. Paseiro, I. Angulo and J. Cruz, " Development of new polyolefin films with nanoclays for application in food packaging", European Polymer Journal, vol. 43, pp. 2229-2243, 2007.

15.D. Pereira, P. Paseiro Losada, I. Angulo, W. Greaves and J. M. Cruz,. "Development of a polyamide nanocomposite for food industry: Morphological structure, processing and properties", Polymer Composites, vol. 30, pp. 436-444, 2009.

16.I. S. Arvanitoyannis and L. Bosnea, "Migration of substances from food packaging materials to foods", Critical Reviews in Food Science and Nutrition, vol. 44, pp. 63-76, 2004.

17.A. T. Sanches Silva, J. M. Cruz Freire, R. Sendón, R. Franz and P. Paseiro Losada, "Migration and diffusion of diphenylbutadiene from packages into foods", Journal of Agricultural and Food Chemistry, vol. 57, pp. 1022510230, 2009.

18.S. Gartner, M. Balski, M. Koch and I. Nehls, "Analysis and migration of phthalates in infant food packed in recycled paperboard", Journal of Agricultural Food Chemistry, vol. 57, pp. 10675-10681, 2009.

19.S. G. Gilbert, J. Miltz and J. R. Giacin, "Transport considerations of potential migrants from food packaging materials", Journal of Food Processing and Preservation, vol. 4, pp. 27-49, 1980.

20.M. J.Shepherd, "The trace contamination of foods by migration from plastics packaging — a review", Food Chemistry, vol. 8, pp. 129-145, 1982.

21.E. A. Tehrany and S. Desobry, "Partition coefficients in food/packaging systems: a review", Food Additives \& Contaminants, vol. 21, pp. 1186-1202, 2004.

22.A. Leo, C. Hansch and D. Elkins, "Partition coefficients and their uses", Chemical Reviews, vol. 71, pp. 525-616, 1971.

23.J. Crank, The Mathematics of Diffusion. (2nd edn). Oxford: Clarendon, 1975.

24.A. Rawe, Principies of polymeric chemistry. New York, United States of America: Plenum Press, 1995.

25.P. Landy, C. Druaux and A. Voilley, "Retention of aroma compounds by proteins in aqueous solution" Food Chemistry, vol. 54, pp. 387-392, 1995.

26.M. Fukamachi, T. Matsui, Y. H. Hwang, M. Shimoda and Y. Osajima, "Sorption behavior of flavor compounds into packaging films from ethanol solution". Journal of Agricultural and Food Chemistry, vol. 44, pp. 2810-2813, 1996.

27.E. A. Tehrany, C. Mouawad and S. Desobry, "Determination of partition coefficient of migrants in food simulants by the PRV method", Food Chemistry, vol. 105, pp. 1571-1577, 2007.

28.M. Shimoda, T. Ikegami and Y. Osajima, "Sorption of flavour compounds in aqueous solution into polyethylene film", Journal of the Science of Food and Agriculture, vol. 42, pp. 157-163, 1988. 
29.T. J. Nielsen, I. M. Jägerstad and R. E. Öste, "Study of factors affecting the absorption of aroma compounds into low-density polyethylene" Journal of the Science of Food and Agriculture, vol. 60, pp. 377-381, 1992.

30.Y. H. Hwang, T. Matsui, T. Hanada, M. Shimoda, K. Matsumoto, and Y. Osajima, "Desorption behavior of sorbed flavor compounds from packaging films with ethanol solution", Journal of Agricultural and Food Chemistry, vol. 48, pp. 4310-4313, 2000.

31.S. Chung and R. Villota, "Changes in partition coefficients of alcohols as affected by the presence of various food solids" Journal of Food Process Engineering, vol. 13, pp. 169-189, 1990.

32.E. Manias, A. Touny, L. Wu, K. Strawhecker, B. Lu and T. C. Chung, "Polypropylene/montmorillonite nanocomposites. Review of the synthetic routes and materials properties", Chemistry of Materials, vol. 13, pp. 3516-3523, 2001.

33.D. A. Pereira de Abreu, J. M. Cruz, I. Angulo and P. Paseiro Losada, "Mass transport studies of different additives in polyamide and exfoliated nanocomposite polyamide films for food industry", Packaging Technology and Science, vol. 23, pp. 59-68, 2010.

34.D. E. Clark, "Rapid calculation of polar molecular surface area and its application to the prediction of transport phenomena. 1. Prediction of intestinal absorption", Journal of Pharmaceutical Sciences, vol. 88, pp. 807-814, 1999. 